\title{
Antioxidant Activity of the Sea Grape (Caulerpa racemasa) Used As an Antioxidant Lotion
}

\author{
ARYANTI SUSILOWATI', ARDI EKO MULYAWAN ${ }^{1 *}$ and TRI WIDAYATI PUTRI ${ }^{1}$ \\ Sekolah Tinggi Teknologi Kelautan Balik Diwa, Makassar, Sulawesi Selatan, Indonesia. \\ ${ }^{*}$ Corresponding author E-mail: ardieko354@gmail.com
}

http://dx.doi.org/10.13005/ojc/350427

(Received: November 03, 2018; Accepted: July 02, 2019)

\begin{abstract}
Caulerpa racemose is one type of seaweed that has the greatest potential in Indonesia. Caulerpa racemose has attracted many attentions as an antioxidant agent which is potential for cosmetic industries. The study aims to analyze the antioxidant content of Caulerpa racemose and determining its effectiveness as an anti-aging lotion. Testing the antioxidant activity of Caulerpa racemosa using the DPPH method. Caulerpa racemosa contains phenol compounds that function as antioxidants. The results showed that value antioxidant activity of Caulerpa racemosa lotion is very higher, value $\mathrm{IC}_{50}$ reach $0,58 \mathrm{ppm}$ (a compound is called a very strong antioxidant if the value of $I C_{50}$ is $<50 \mathrm{ppm}$ ) and the results test of Caulerpa racemose lotion was appropriate with quality standard SNI 16-4399-1996 about the standards sunscreen preparations for the skin. This paper presents the first-time production lotion from Caulerpa racemose.
\end{abstract}

Keywords: Anti-aging lotion, Caulerpa racemose, Antioxidant, DPPH.

\section{INTRODUCTION}

One of the seaweed type in Indonesia that is quite promising is Caulerpa racemosa or sea grape. Caulerpa racemosa production is 10.3 million tons per year and increases every year ${ }^{1}$. This species in South Sulawesi is commonly known as lawi-lawi or bu'ne while in Java it is known as latoh.

Caulerpa racemosa has high nutritional content such as vegetable protein, minerals and vitamins ${ }^{2}$. Moreover, Caulerpa racemosa has bioactive compound like tannin, phenol, flavonoid, alkaloid that can inhibit the growth of bacteria and fungi, so that can be used in medical and cosmetic fields ${ }^{3,4}$. Phenol compounds found in Caulerpa racemose act to protect body cells from free radical damage by binding to free radicals so as to prevent inflammation and inflammation in the body's cells ${ }^{5}$.

Caulerpa racemosa is very common in coastal areas and coral reefs. In its utilization, this type of seaweed. Caulerpa racemosa is still very rarely processed $^{6}$. One of the promising products of Caulerpa racemosa is the manufacture of lotions because they are rich in antioxidants which are good for the skin.

This is an Open Access article licensed under a Creative Commons license: Attribution 4.0 International (CC- BY). Published by Oriental Scientific Publishing Company @ 2018

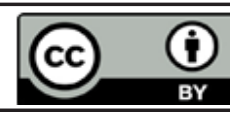


A lotion is a form of an emulsion that is defined as a mixture of two or more phases, namely water and fat, which is stabilized with an emulsion system and if placed at room temperature will be a liquid?. The function of skin lotion is that it can maintain skin moisture, soften skin, prevent water loss and cleanse skin ${ }^{8}$. The study aims to analyze the antioxidant content of Caulerpa racemose and determining its effectiveness as an anti-aging lotion. The manufacture of lotions from Caulerpa racemosa is one of a promising process that can be done to increase the selling value of Caulerpa racemose.

\section{MATERIAL AND METHODS}

The equipment used in the research is analytical scale, mortar and pestle, hotplate stirrer, oven, Ostwald viscometer, drop pipette, beaker, measuring flask, pycnometer, $\mathrm{pH}$ meter, petri dish and spectrophotometer UV-Vis US-110PC. The materials used in the research are Caulerpa racemosa, nipagin and nipasol, propylene glycol, stearic acid, triethanolamine, DPPH, vitamin C pa, aquades, aqubides, filter paper, $\mathrm{pH}$ buffer and label paper.

\section{Production of Caulerpa racemose lotion}

Production of Caulerpa racemose lotion and control composed of two phases namely oil phase and an aqueous phase. For Oil phase, dissolve Caulerpa racemose and stearic acid in a hot mortar and added TEA. For Aqueous phase, dissolve nipagin and nipasol with propylene glycol and added aquades. Then mix the two phases to form a lotion?. For control lotion the production without the addition of Caulerpa racemose.

Tabel 1: Formulation of Caulerpa racemose lotion ${ }^{9}$

\begin{tabular}{lcc}
\hline Materials & Control & Caulerpa racemose \\
\hline Caulerpa racemosa & $\mathrm{x}$ & 10 \\
Stearic Acid & 14,2 & 14,2 \\
Triethanolamine & 1 & 1 \\
Nipagin & 0,1 & 0,1 \\
Nipasol & 0,05 & 0,05 \\
Propilenglikol & 5 & 5 \\
Aquades & 100 & 100 \\
\hline
\end{tabular}

The Caulerpa racemose lotion then tested according to SNI 16-4399-1996 standard that is an organoleptic test, $\mathrm{pH}$, density, viscosity and microbial contamination.

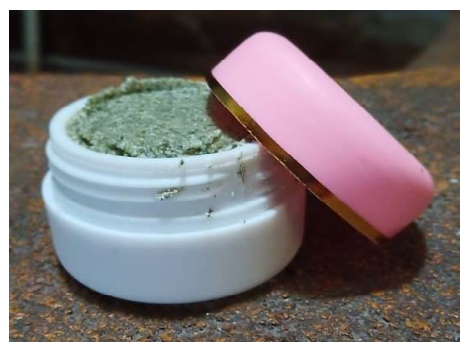

Fig. 1. Caulerpa racemosa lotion and control lotion

\section{Testing of Caulerpa racemose lotion \\ DPPH solution}

Weighed as much as $10.0 \mathrm{mg}$ of DPPH (2,2diphenyl-1-pikril hydrazine) then dissolved in ethanol p. a. using a volumetric flask $100 \mathrm{~mL}$, as a stock solution. For a concentration of $0.125 \mathrm{ppm}, \mathrm{DPPH}$ solution was pipetted as much as $1.50 \mathrm{ml}$ then the volume was filled with ethanol p.a to $10.0 \mathrm{ml}$ and the absorbance was observed in a spectrophotometer. Performed again for each concentration of 0.25 ppm, $0.5 \mathrm{ppm}$, and $0.75 \mathrm{ppm}$. The solutions is then transferred to a brown glass and allowed to stand for 30 min then the absorption is measured at the maximum DPPH wavelength of $515 \mathrm{~nm}$.

\section{Testing of Caulerpa racemose lotion Antioxidant activity using DPPH method}

As much as $2.5 \mathrm{~g}$ of a lotion is put into a mortar, then added $5.0 \mathrm{~mL}$ ethanol p. a. Then centrifuged for 10 min then filtered with filter paper until the solution is clear. The filtrate was put into a volumetric flask, added $2.0 \mathrm{~mL}$ of DPPH solution and the volume was filled with ethanol p. a. up to $10 \mathrm{~mL}$, incubated at $37^{\circ} \mathrm{C}$ for $30 \mathrm{~min}$ put in a cuvette, then absorbed using a Spectrophotometer UV-Vis with a wavelength of $515 \mathrm{~nm}$. Antioxidant activity is expressed by\% inhibition.

$\%$ inibition $=\underline{\text { Abscontrol-Abssample }} \times 100 \%$ Information :

$$
\text { Abscontrol }
$$

$$
\begin{aligned}
& \text { Abs Kontrol : Solution+ DPPH } \\
& \text { Abs Sample : Solution + DPPH + Sample }
\end{aligned}
$$

Specifically, a compound is called a very strong antioxidant if the $\mathrm{IC}_{50}$ value is $<50 \mathrm{ppm}$, it is stated strongly if the $\mathrm{IC}_{50}$ value is $50-100 \mathrm{ppm}$, expressed as a medium if the $\mathrm{IC}_{50}$ value is $101-150 \mathrm{ppm}$, and is declared weak if the $\mathrm{IC}_{50}$ value is $>150 \mathrm{ppm} .{ }^{10}$

To find out the lotion quality of Caulerpa racemosa, measurement of $\mathrm{pH}$ value, viscosity, 
density and total microbial contamination need to be considered so as to get a quality lotion.

\section{RESULT AND DISCUSSION}

\section{Antioxidant activity of Caulerpa racemose lotion}

DPPH (1,1-diphenyl-2-picrylhydrazyl) is a free radical that can react with compounds that can donate hydrogen or proton atoms, thus forming non-radical compounds that are non-radical DPPH used in testing antioxidant activity in an ingredient/ extract. Due to of unpaired electrons, DPPH gives a strong absorption at an absorbance of about $517 \mathrm{~nm}$. When the electrons become paired by the presence of free radical catchers the absorbance decreases stoichiometrically according to the number of electrons taken. The presence of antioxidant compounds can change the color of DPPH solution from purple to yellow. ${ }^{11}$

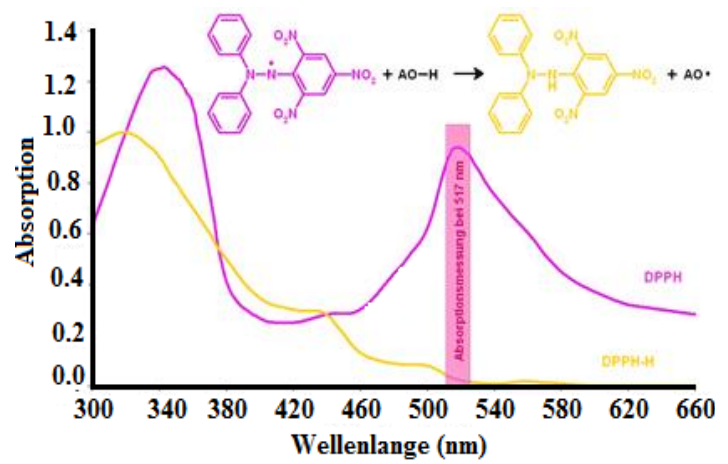

Fig. 2. Discoloration of the solution in DPPH radical reaction with antioxidants ${ }^{12}$

Determination of antioxidant activity from lotions by graphing the relationship between concentration (ppm) and \% inhibition. The equation of the regression obtained from the graph is used to calculate the value of Inhibition Concentration $\left(\mathrm{IC}_{50}\right)$.

Calculation of $\mathrm{IC}_{50}$ value for control lotion based on graph results:

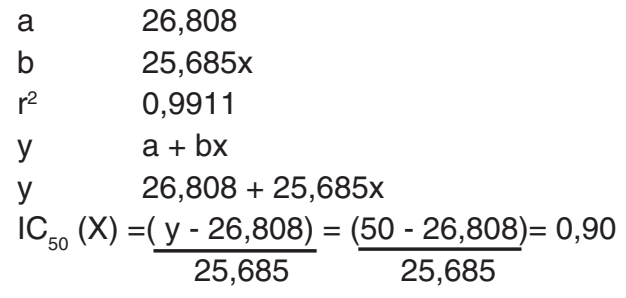

Calculation of $\mathrm{IC}_{50}$ value for Caulerpa racemose lotion based on graph results:
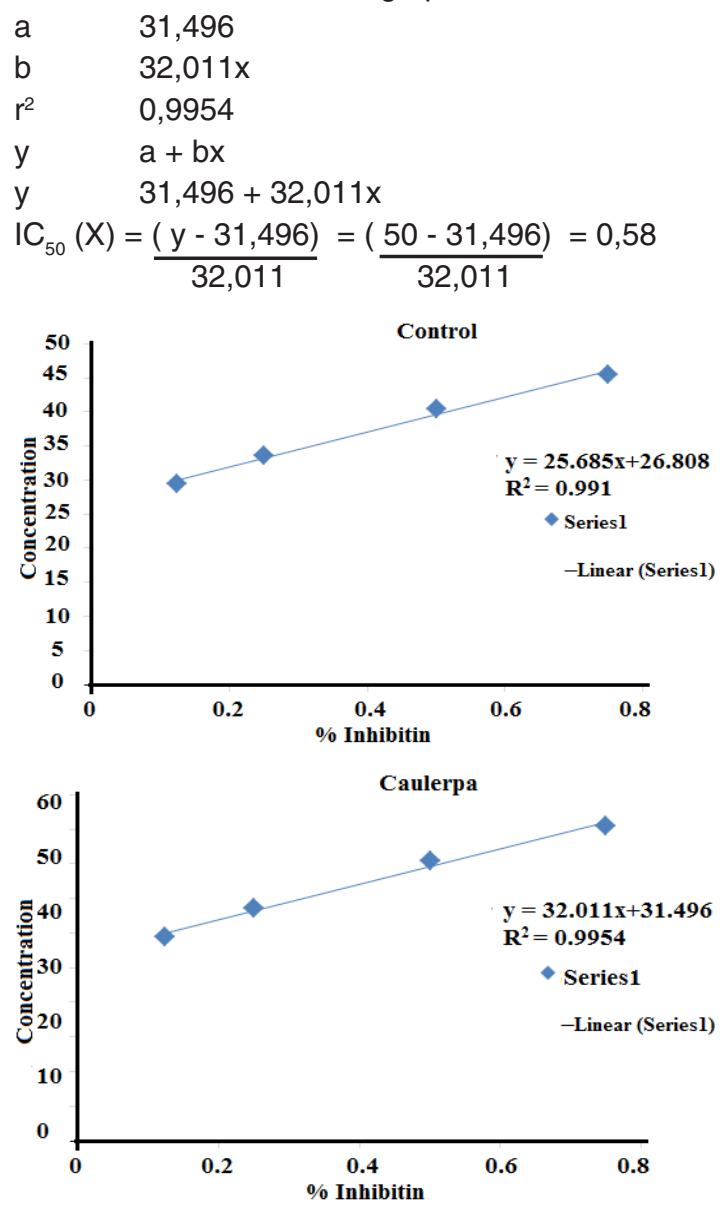

Fig. 3. Graph of measurements of control lotion and Caulerpa racemose lotion

Table 2: The result of Antioxidant activity from Caulerpa racemosa lotion and control lotion

\begin{tabular}{|c|c|c|c|c|c|c|c|}
\hline No & Sample & Sample weight & Concentration & Absorbance Sample & Absorbance DPPH & $\%$ antioxidant & $\mathrm{IC}_{50}$ \\
\hline \multirow[t]{4}{*}{1} & Control & 1.425 & 0.125 & 0.525 & 0.905 & 29.47 & 0.90 \\
\hline & & 1.425 & 0.250 & 0.473 & 0.905 & 33.50 & \\
\hline & & 1.425 & 0.500 & 0.383 & 0.905 & 40.48 & \\
\hline & & 1.425 & 0.750 & 0.318 & 0.905 & 45.52 & \\
\hline \multirow[t]{4}{*}{2} & Caulerpa racemosa & 1.095 & 0.125 & 0.557 & 0.905 & 35.12 & 0.58 \\
\hline & & 1.095 & 0.250 & 0.506 & 0.905 & 40.26 & \\
\hline & & 1.095 & 0.500 & 0.440 & 0.905 & 46.92 & \\
\hline & & 1.095 & 0.750 & 0.353 & 0.905 & 55.70 & \\
\hline
\end{tabular}


Caulerpa racemosa lotion has strong antioxidant activity compared to control lotions or without the addition of Caulerpa racemosa. $\mathrm{IC}_{50}$ values less than $0.05 \mathrm{mg} / \mathrm{mL}$ or $50 \mathrm{ppm}$ identify that the lotion has very strong antioxidant activity. The high value of anti-oxidant activity in the lotion Caulerpa racemosa due to Caulerpa racemosa has a bioactive component that is the content of polyphenol compounds which have hydroxy groups substituted in ortho positions and para to - $\mathrm{OH}$ and -OR groups so that the compounds have antioxidant activity.<smiles>CC([PH2+])C(C)Cc1cc(O)ccc1O</smiles>

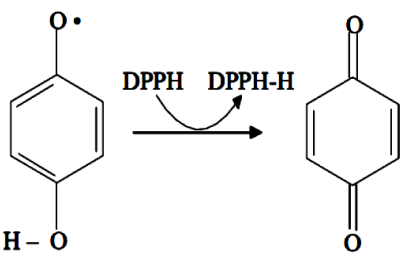

Fig. 4. The reaction of phenolic compounds with $\mathrm{DPPH}^{13}$

\section{pH Value}

$\mathrm{pH}$ lotion testing was carried out at the beginning of manufacture and for 4 weeks storage using a $\mathrm{pH}$ meter. Lotion with too acidic $\mathrm{pH}$ can irritate the skin while lotions that are too alkaline can make the skin dry so the preparation must have a $\mathrm{pH}$ that is suitable for the skin.

Table 3: pH value of Caulerpa racemosa lotion and control lotion

\begin{tabular}{ccc}
\hline Sample & Initial pH & pH after 4 weeks \\
\hline Control & 8,02 & 8,15 \\
Caulerpa racemosa & 6,12 & 5,74 \\
\hline
\end{tabular}

The results of $\mathrm{pH}$ measurements showed that the $\mathrm{pH}$ value of Caulerpa racemosa lotion was 6.12 and after 4 weeks of storage the $\mathrm{pH}$ value decreased to 5.74. Decreasing the $\mathrm{pH}$ of the lotion Caulerpa racemosa can be caused by the hydrolysis of acidic compounds that can be triggered by an increase in temperature during storage. However, based on Sunscreen Quality Standards (SNI 16-4399-1996) the $\mathrm{pH}$ value requirements are safe for the skin, namely $\mathrm{pH} 4.5-8.0$ so that the $\mathrm{pH}$ of this lotion has fulfilled these requirements. While the control lotion had an initial $\mathrm{pH}$ of 8.02 and after 4 weeks of storage, the $\mathrm{pH}$ increased to 8.15 , due to the water phase and oil phase on the control lotion begins to decompose so that the $\mathrm{pH}$ value of the control lotion increases.

\section{Viscosity}

Viscosity test is done to determine the thickness of a sample from the resistance of a substance to flow. The higher the flow viscosity, the greater the resistance. Viscosity affects the rate of absorption of lotion on the skin, the thicker the longer the absorption of the drug will be. The lotion measured its initial viscosity and after being stored for 4 weeks at room temperature.

Table 4: Viscosity value of Caulerpa racemosa lotion and control lotion

\begin{tabular}{ccc}
\hline Sample & $\begin{array}{c}\text { Initial viscosity } \\
\text { (Cps) }\end{array}$ & $\begin{array}{c}\text { viscosity after } \\
\text { 4 weeks (Cps) }\end{array}$ \\
\hline Control & 53,4 & 73,40 \\
Caulerpa racemosa & 900 & 1100 \\
\hline
\end{tabular}

Note : The fluidity unit is the centipoise (cps)

Viscosity is influenced by the selection of lotion ingredients, such as surfactants, disperse particles and the proportion of both water and oil phases. The viscosity value for control lotions is very low compared to lotions with the addition of Caulerpa racemosa. Viscosity value increases after 4 weeks of storage. This increase occurred due to evaporation of ethanol in the lotion so that the lotion thickened.

\section{Density}

Density is used to determine the absorption standard of a preparation. The smallest density identifies that the lotion has good homogeneity. The density of lotion types Caulerpa racemosa and control lotions are still in accordance with the quality standards of SNI 16-4399-1996, namely 0.95-1.05 g/mL.

Table 5: The density value of Caulerpa racemosa lotion and control lotion

\begin{tabular}{ccc}
\hline Sample & $\begin{array}{c}\text { Initial density } \\
(\mathrm{g} / \mathrm{mL})\end{array}$ & $\begin{array}{c}\text { density after } \\
\text { 4 weeks }(\mathrm{g} / \mathrm{mL})\end{array}$ \\
\hline Control & 0,9862 & 0,9793 \\
Caulerpa racemosa & 1,0255 & 1,0394 \\
\hline
\end{tabular}

Total Microbial Contamination

Based on the Regulation of the Head of the Indonesian Drug and Food Control Agency No. HK.00.06.1.52.4011 in 2009, concerning the determination of the maximum limits of microbial and chemical contamination. Microbial contamination is contamination from microbes that can be harmful one of which is Escherichia choli. ${ }^{14}$

The results of the total microbial contamination test on the lotion in accordance with the sunscreen quality standards SNI 16-4399-1996 that is a maximum of 102 colonies/gram. 
Tabel 6: Total microbial contamination

\begin{tabular}{ccc}
\hline Sample & Value of SPC (CFU) & Escherichia choli \\
\hline Caulerpa & $10 \times 10^{3}$ & - \\
Kontrol & $25 \times 10^{3}$ & - \\
\hline Note : CFU is Colony Forming Unit \\
SPC is Standard Plate Count
\end{tabular}

Antimicrobial test results showed that both lactic acid bacteria isolates from Caulerpa racemosa lotion and control lotions were able to inhibit E.coli. Organic acids produced by lactic acid bacteria are lactic acid and acetic acid. Lactic acid is the main metabolite of lactic acid bacteria. The inhibitory effect occurs because organic acid molecules enter the cell membrane and reduce the cytoplasmic $\mathrm{pH}$. Hydrogen peroxide produced by the activity of lactic acid bacteria can inhibit pathogenic bacteria ${ }^{15}$.

In addition, other acids are produced by lactic acid bacteria such as acetic acid, propionate and formiate, although the production is small, but has stronger antimicrobial power than lactic acid. Lactic acid and a little acetic acid formed have an inhibitory effect on pathogenic microbes, apart from being caused by a decrease in $\mathrm{pH}$ below the optimum $\mathrm{pH}$ of pathogenic microbial growth, the presence of undissociated acid molecules that can penetrate the cell wall and disrupt the metabolic process and genetic mechanisms of pathogenic bacterial cells ${ }^{16}$

\section{Profile of Caulerpa racemose lotion}

The results test of Caulerpa racemose Iotion was appropriate with quality standard SNI 16-4399-1996 about the standards of good cosmetic production. Caulerpa racemosa lotion has a pH is 5.72 ; density is $1,0255 \mathrm{~g} / \mathrm{cm}^{3}$ and viscosity is $900 \mathrm{Cps}$.

\section{CONCLUSION}

Based on the results of research, it can be concluded that value antioxidant activity of Caulerpa racemosa lotion is very higher, value $\mathrm{IC}_{50}$ reach 0,58 ppm using DPPH method (a compound is called a very strong antioxidant if the value of $\mathrm{IC}_{50}$ is $<50 \mathrm{ppm}$ ) and the results test of Caulerpa racemose lotion i.e $\mathrm{pH}$ is 6,15; viscosity is 900 ; density is 1,0255 ; Total microbial contamination is $10 \times 10^{3}$. It's appropriate with quality standard SNI 16-4399-1996 about the standards sunscreen preparations for the skin.

\section{ACKNOWLEDGMENT}

The authors are thankful to Laboratorium at Hasanuddin University to analyze the sample and for their support and co-operation. And authors are Grateful to DRPM Kemenristekdikti Contract Number :1167/K9/KT.03/2018 for providing financial assistance in the form of the grant.

\section{Conflicts of Interest}

The authors declare no conflict of interest.

\section{REFERENCES}

1. Ginting, E. S; Rejeki.S.; and Susilowati. T. Journal of Aquaculture Management and Technology., 2015, 4(4), 82-87.

2. Ma'ruf, W. F.; Ibrahim, R.; Dewi, E. N.; Susanto, E.; and Amalia, U. Jurnal Saintek Perikanan., 2013, 9(1), 68-74.

3. Chew, Y.L.;Y.Y.Lim, M. Omar and K.S.Khoo. Food Science and Technology., 2008. 41, 1067-1072.

4. Marfuah, I.; Dewi, E.N. and Rianingsih, L. J. Peng. \& Biotek., 2018, 7, 1.

5. Saputra. A.;Wike, A.E.P. and Riris, A. Maspari Journal., 2011, 3(1), 30-35.

6. Yudasmara, G.A. Journal Sains dan Teknologi., 2014, 3(2), 468-473.

7. Purwaningsih, S.; Salamah, E.; and Budiarti, T. K. Journal Akuatika., 2014, 5, 0853-2532.

8. Purwaningsih, S.; Salamah, E. and Budiarti, T.A. Journal Akuatika., 2014, 5(1), 55-62.

9. Putri, T.W.; Raya, I.; Natsir, H.; And Mayasari,
E. Orient. J. Chem, 2017, 33(6), 2848-2857.

10. Garcia, E. J; Oldoni, T.L; Alencar, S.M.; Reis. A.; Loguercio, A. Braz Dent J., 2012, 23(1), 22-27.

11. Ridhowati, S. and Asnani. Oseana., 2016, (51)4, $50-62$.

12. Witt, S.;Lalk, M.; Hager, C.; and Voigt, B.DPPH-Test: Determination of Scavenger Properties., 2010.

13. Cholisoh, Z., dan Wahyu, U., Aktivitas Penangkap Radikal Ekstrak Ekstrak Etanol 70\% Biji Jengkol (Archidendron jiringa), Pharmacon., 2008, 9(1), 3340.

14. Badan Pengawasan Obat dan Makanan Republik Inddonesia. Nomor HK.00.06.1.52.4011 Tentang Penetapan Batas Maksimum Cemaran Mikroba dan Kimia dalam Makanan., 2009.

15. Setiarti, R. H.B.; Widyastuti, N. and Rikmawati, N.A. Journal Veteriner., 2017, 18(3), 428-440.

16. Meidong, R.; Doolgindachbaporn, S.; Sakai, K.and Tongpim, S. AACL Biolux., 2017, 10(2), 455-463. 